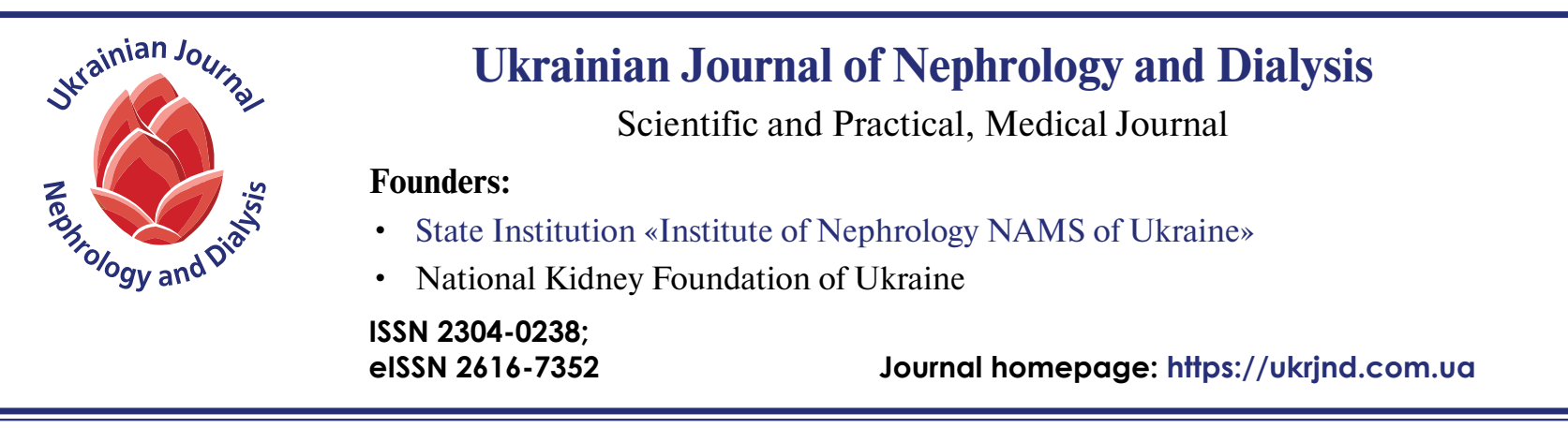

\section{Nephrology School}

doi: 10.31450/ukrjnd.2(70).2021.09

\section{Olga Kompaniets}

\section{Hyperuricemia and chronic kidney disease}

State Institution "Institute of Nephrology of the National Academy of Medical Sciences of Ukraine”, Kyiv, Ukraine

\section{Article history:}

Received March 03, 2021

Received in revised form

March 23, 2021

Accepted March 25, 2021
Kompaniets O. Hyperuricemia and chronic kidney disease. Ukr J Nephr Dial. 2021;2(70):77-81. doi: 10.31450/ukrjnd.2(70).2021.09

Abstract. The article is devoted to a review of the literature on the impact of hyperuricemia on the development and progression of chronic kidney disease (CKD). The tendency of changes of views on the role of uric acid in the pathogenesis of CKD is demonstrated. An analysis of experimental, epidemiological and clinical studies on the effects of uric acid on the physiology of the nephron and endothelial tissues, the relationship of hyperuricemia with metabolic and cardiorenal syndromes.

Key words: chronic kidney disease, hyperuricemia, uric acid, gouty nephropathy, cardiorenal syndrome, endothelial dysfunction, metabolic syndrome.

Conflict of interest statement. The author declares no competing interest.

(C) Kompaniets O., 2021. All rights reserved. 
(C) Компанієць О., 2021.

УДК: 616.633.857.5:616.61-036.12

\title{
О.Л. Компанієць
}

\section{Гіперурикемія та хронічна хвороба нирок}

\author{
ДУ «Інститут нефрології НАМН України», Київ, Україна
}

Резюме. Стаття присвячена огляду літератури щодо впливу гіперурикемії на розвиток та прогресування хронічної хвороби нирок (ХХН). Продемонстровано тенденцію змін поглядів на роль сечової кислоти у патогенезі ХХН. Представлено аналіз експериментальних, епідеміологічнихі та клінічних досліджень з питань зв'язку гіперурикемії з метаболічним та кардіо-ренальним синдромами.

Ключові слова: хронічна хвороба нирок, гіперурикемія, сечова кислота, подагрична нефропатія, кардіоренальний синдром, ендотеліальна дисфункція, метаболічний синдром.

Впродовж останніх ста п'ятдесяти років думка фахівців щодо ролі сечової кислоти, яка являє собою кінцевий продукт пуринового обміну, у розвитку хронічної хвороби нирок (ХХН) змінювалася кілька разів. У 1776 році шведський фармацевт Карл Вільгельм Шеле, досліджуючи конкременти сечового міхура, вперше відкрив сечову кислоту та задокументував взаємозв'язок між підвищеним рівнем сечової кислоти в сироватці крові та подагрою [1]. Подагра вважалася однією 3 провідних причин ХХН в середині ХІХ століття, і у своїх чисельних дослідженнях д-р Талботт і д-р Терплан спостерігали, що майже $100 \%$ пацієнтів з подагрою мали ознаки ХХН та спостерігали під час розтину артеріолосклероз, гломерулосклероз та інтерстиціальний фіброз [1].

Оскільки гіперурикемія призводить до відкладення уратних кристалів у тканинах, викликаючи гострий подагричний артрит, уролітіаз, обструктивну нефропатію, захворювання стало відоме як подагрична або уратна нефропатія. Однак, з часом з'ясувалась, що уратна нефропатія не завжди асоційована з ХХН і більшість пацієнтів має супутню артеріальну гіпертензію, що змусило деяких експертів припустити, що пошкодження нирок у хворих на подагру може бути викликано іншим ніж гіперурикемія причинами [1]. Подагру і уратурію, як причину ХХН, було вилучено з підручників і загальний зв'язок гіперурикемії з ХХН пояснювався лише підвищенням сечової кислоти крові, яка, у свою чергу, є наслідком зниження швидкості клубочкової фільтрації (ШКФ) [2]. Близько 50 років тому, після експериментально продемонстрованого прогресування ХХН асоційованого виключно з гіперурикемією, відновився інтерес наукової спіль-

\section{Ольга Леонідівна Компанієць olga003@ukr.net}

ноти до потенційної ролі сечової кислоти у прогресуванні гострої і хронічної хвороби нирок [2].

Гіперурикемія - це персистуюче підвищення концентрації сечової кислоти плазми крові вище 360 мкмоль/л у жінок та 420 мкмоль/л у чоловіків, під дією якої у тканинах суглобів або нирок може відбуватися накопичення мононатрійових уратних кристалів [3]. Причини гіперурикемії включають генетичні фактори, надмірне споживання алкоголю, пурин-збагачену дієту, метаболічний синдром, використання діуретиків та зниження ШКФ [3]. Серед спадкових причин виділяють дефекти генів, що відповідають за активність ферментів, які впливають на синтез та екскрецію сечової кислоти нирками [3].

Баланс сечової кислоти в організмі людини відбувається переважно за рахунок ниркової екскреції (80\%), тоді як кишкова екскреція уратів складає близько $20 \%$ [3]. Нирковий шлях елімінації СК умовно поділяють на 4 послідовні фази: 1) повна фільтрація; 2) повна реабсорбція у проксимальних ниркових канальцях; 3) секреція (близько 50\% від реабсорбованих); 4) повторна реабсорбція у дистальних ниркових канальцях (40\% від секретованих). У фізіологічних умовах кліренс сечової кислоти приблизно складає $10 \%$ від ШКФ, що у середньому становить $8,7 \pm 2,5$ мл/хв/1.73 м². Урати крові активно фільтруються гломерулярним апаратом та реабсорбуються значною мірою в проксимальних відділах клубочків [4]. Обидва процеси здійснюються за рахунок мембранних уратних транспортерів. Тільки 3-10\% відфільтрованих уратів екскретуються з сечею, інша частина (90-97\%) реабсорбується в проксимальних відділах ниркових канальців [4].

Неекскретована сечова кислота депонується в тканинах і фагоцитується макрофагами, внаслідок чого активуються інфламасоми, CASP1, IL-1 $\beta$, що обумовлює розвиток запального процесу в ендотелії судин. Інфламасоми - це комплекс протеїнів, що викликає перехід прозапальних цитокінів в їх активний стан. Ідентифіковані 4 типи інфламасом: NLRP1, NLRP2, AIM2, IPAF [5]. Каспази, 
згідно Вікіпедії - це протеїни, що розташовані в цитоплазмі клітин і відповідають за апоптоз та альтернативний сплайсінг [5]. Крім цього, кристали сечової кислоти активують циклооксигеназу (COX)-2, кіназу (Syk, p38 MAPK) та інтерлейкін IL-1 $\beta$, останньому належить важлива роль у розвитку подагри [6].

В сечі сечова кислота існує у двох формах: розчинній - у вигляді урата (іонізована форма, не поєднана із транспортними білками) і нерозчиненій (відрізняється одним іоном водню, який має здібність поєднуватися з уратом за $\mathrm{pH}<5,5)$. У хворих 3 гіперурикемією кількість іонів водню підвищена внаслідок дефекту екскреції уринарного буфера, який виникає внаслідок дефекту синтезу глютамінази i/або глютаматдегідрогенази. Саме велика кількість іонів водню обумовлює поєднання водню з уратом [6].

3 крові урати надходять у кишечник шляхом секреції, а також як компонент жовчі, слини, шлункового соку [7]. Сечова кислота не виводиться з калом в чистому вигляді, оскільки розпадається в кишечнику до $\mathrm{CO}_{2}$ та алантоїну. Вперше роль кишківника в екскреції уратів була описана досить давно [7]. Продемонстровано, що при введенні уратів щурам значна частина речовини виділяється через кишечник, тоді як через жовч урати виділялися в мінімальній кількості, адже пряма інтестинальна секреція є одним із компонентів екскреції уратів і важливим альтернативним шляхом їх виведення у пацієнтів з ХXН [8]. Однак й досі мало досліджень, які пояснюють механізми інтестинального уриколізу, що потребує подальшого вивчення [8].

Сечова кислота у підвищених титрах має прозапальні та проатерогенні ефекти: стимуляція проліферації гладеньких м'язів ендотелію, активацію макрофагів з вивільненням хемокинів та медіаторів запалення ( інтерлейкіни: IL-1 $\beta,-6,-8$; ФНО- $\alpha$, фосфоліпаза A2, ейкозаноїди, кініни и т.д.) [8].

Серед інших факторів ризику гіперурикемії також обговорюється генетичні детермінанти нефролітіазу: ген ZNF365 (Zinc finger protein 365) на хромосомі 10q21-q22 і ген SLC2A9 (Solute carrier family 2 member 9), що відповідальний за кодування URAT1 (Urate transporter 1) [9].

Підвищений рівень сечової кислоти в сироватці крові сприяє порушенню продукції оксиду азоту / дисфункції ендотелію, підвищеній жорсткості судин, неадекватній активації системи ренін-ангіотензин-альдостерон, посиленню окисного стресу та неадаптивним імунним та запальним реакціям. Ці відхилення, в свою чергу, сприяють розвитку судинного, серцевого та ниркового фіброзу, а також пов'язаних 3 ними функціональних відхилень [10].

Експериментально продемонстровано, що гіперурикемія може призводити як до уратної нефропатії без випадіння кристалів, так і до склерозу клубочків нирок, фіброзу інтерстиція і ураження ендотелію артеріол [11]. Саме тому, у пацієнтів 3 клінічними ознаками порушення обміну сечової кислоти спостерігаються абдомінальне ожиріння, інсулінорезистентність, цукровий діабет II типу та артеріальна гіпертензія. Зв'язок 3 інсулінорезистентністю двобічний: інсулінорезистентність призводить до підвищеної канальцевої реабсорбції натрію і зниженню екскреції сечової кислоти нирками, що є причиною гіперурикемії, яка обумовлює підвищення глікозильованого гемоглобіну (HbA1c). HbA1c, у свою чергу, виступає предиктором розвитку цукрового діабету II типу $[13,14]$.

У хворих з артеріальною гіпертензією гіперурикемія асоційована 3 дисфункцією ендотелію та мікроальбумінурію, що призводить до формування гломерулярної гіпертензії та порушення ниркової гемодинаміки [13]. Крім того, встановлено, що гіперурикемія у пацієнтів із гіпертонічною хворобою асоціюється $з$ основними компонентами метаболічного синдрому: абдомінальним ожирінням, порушеною толерантністю до глюкози, гіперінсулінемією та дисліпротеїнемією $[13,15]$.

При ожирінні, особливо при збільшеному споживанні фруктози спостерігається підвищена печінкова продукція сечової кислоти [16]. Зі зниженням швидкості клубочкової фільтрації (ШКФ) рівень сечової кислоти в сироватці крові поступово зростає, і приблизно 50\% ниркових пацієнтів мають гіперурикемію на момент початку діалізу [17]. Незважаючи на те, що гіперурикемія та гіперінсулінемія тісно пов'язані між собою, механізми цієї асоціації залишаються незрозумілими. Один із механізмів, ймовірно, пов'язаний з тим, що гіперурикемія сприяє підвищенню інсулінорезистентності та асоційованій гіперінсулінемії [18]. На функцію канальців нирок впливає метаболічний сигнал інсуліну, а кліренс сечової кислоти в сечі зменшується із зменшенням утилізації глюкози, опосередкованої інсуліном [19]. Нещодавні дослідження показали, що жирова тканина може виступати як ендогенне джерело сечової кислоти, і що сечова кислота посилює запальну інфільтрацію макрофагів та запалення в жировій тканині [19].

Тобто, гіперурикемія запускає потенційні патофізіологічні механізми, які сприяють розвитку серцево-судинних захворювань та ХХН [20]. Підвищений рівень сечової кислоти сироватки крові сприяє порушенню продукції оксиду азоту / дисфункції ендотелію, неадекватній активації ренінангіотензин-альдостеронової системи, оксидативному стресу, розвитку імунних та запальних реакцій, які ініціюють розвиток судинного, серцевого та ниркового фіброзу й пов'язаних з ними функціональних відхилень [21-23].

$\mathrm{E}$ все більше доказів того, що зниження рівня сечової кислоти в сироватці крові є стратегічно важливою для зниження артеріального тиску. Наприклад, у рандомізованому, подвійному сліпому, плацебо контрольованому дослідженні, у якому 
брали участь 30 підлітків із вперше діагностованою, ніколи не лікуваною есенціальною гіпертензією першої стадії та рівнем сечової кислоти в сироватці $\geq 6$ мг / дл, після лікування алопуринолом, показники зниження середнього систолічного і діастолічного тиску, а також цілодобового амбулаторного артеріального тиску були значно краще, ніж у групі плацебо [24]. У дослідженні вагітних жінок середні показники сечової кислоти в сироватці крові у жінок з прееклампсією були високими, а рівні сечової кислоти в сироватці $\geq 5,5$ мг / дл вказували на підвищену ймовірність прееклампсії у вагітних пацієнтів 3 гіпертонічною хворобою [25]. Більше того, у рандомізованому контрольованому дослідженні чоловіки, яким вводили 200 г фруктози щодня протягом 2 тижнів, демонстрували збільшення 24-годинного амбулаторного артеріального тиску, що було запобігнуто одноразовим введенням алопуринолу [25]. Ці результати підтверджують уявлення про те, що споживання продуктів з високим вмістом фруктози та гіперурикемія підвищують кров яний тиск, і що зниження сечової кислоти за допомогою алопуринолу знижує кров яний тиск, а також пов язаний з цим ризик розвитку серцевосудинних захворювань [25].

Останніми роками широко обговорюється роль сечової кислоти, як незалежного предиктора прогресування ХХН. В експериментальних роботах гіперурикемія призводила до підвищення рівня протеїнурії та ниркової недостатності [25]. Нещодавні клінічні дослідження також продемонстрували, що концентрація сечової кислоти сироватки є незалежним фактором ризику зниження ШКФ < 60 мл/хв/1,73 м² у хворих на гломерулонефрит, незалежно від наявності нефротичного синдрому [22, 26]. Автори показали, що гіперурикемія майже у 20 разів підвищує ризик прогресування ХХН, навіть після поправки на альбумінемію, креатинінемію, загальну протеїнемію, добову протеїнурію, вік пацієнтів та артеріальну гіпертензію [27].

Проте, слід зазначити, що нормальна концентрація сечової кислоти є антиоксидантною молекулою, яка активує епітеліальні клітини для вивільнення TSLP (Thymic stromal lymphopoietin) та IL-33 (Interleukin 33), але не IL-25 (Interleukin 25), та індукує імунну реакцію 2 типу [28]. Ці властивості можуть пояснити захисний потенціал сечової кислоти у хворих з неврологічною та інфекційною патологією, хоча механізм дії сечової кислоти остаточно не з'ясований [28].

Таким чином, підвищення концентрації сечової кислоти крові може бути незалежним фактором ризику розвитку та прогресування ХХН. Подальші дослідження необхідні для остаточного визначення її ролі у генезі ХХН і розвитку метаболічного та кардіо-ренального синдрому. Оскільки консенсус щодо лікування безсимптомної гіперурикемії наразі відсутній, існує необхідність провести більше за обсягом рандомізованих контрольованих досліджень, щоб критично оцінити корисний ефект зниження рівня сечової кислоти в сироватці крові у пацієнтів з безсимптомною гіперурікемією, а також при кардіоренальному і метаболічниму синдромі.

\section{References (Література):}

1. Richard J Johnson 1, Takahiko Nakagawa, Diana Jalal, Laura Gabriela Snchez-Lozada, Duk-Hee Kang, Eberhard Ritz. Uric acid and chronic kidney disease: which is chasing which? Nephrol Dial Transplant 2013;28:2221-28. doi: 10.1093/ndt/ gft029.

2. Barlow $K A$, Beilin LJ. Renal disease in primary gout. Q J Med. 1968;37(145):79-96.

3. Шуба НМ. Гиперурикемия - мультиморбидная патология в ревматологии. Український ревматологічний журнал 2013;52(2):14-22.

4. Terkeltaub R, Bushinsky DA, Becker MA. Recent developments in our understanding of the renal basis of hyperuricemia and the development of novel antihyperuricemic therapeutics. Arthritis Res Ther. 2006;8 Suppl 1(Suppl 1):S4. doi: 10.1186/ar1909.

5. Rabadi MM, Kuo MC, Ghaly $T$, et al. Interaction between uric acid and HMGB1 translocation and release from endothelial cells. 2012;302(6):F730F741. doi: 10.1152/ajprenal.00520.2011.

6. Weaver DJ Jr. Uric acid and progression of chronic kidney disease. Pediatr Nephrol. 2019;34(5):801809. doi: 10.1007/s00467-018-3979-2.
7. Mazzali M, Kanellis J, Han L, Feng L, Xia Y, Chen Q, et al. Hyperuricemia induces a primary renal arteriolopathy in rats by a blood-pressure-independent mechanism Am J Physiol 2002 282:6, F991-F997. doi: 10.1152/ajprenal.00283.2001.

8. Pacifico L, Cantisani $V$, Anania $C$, Bonaiuto E, Martino F, Pascone $R$, et al. Serum uric acid and its association with metabolic syndrome and carotid atherosclerosis in obese children. Eur J Endocrinol. 2009 Jan;160(1):45-52. doi: 10.1530/ EJE-08-0618.

9. Bagnati M, Perugini $C$, Cau C, Bordone R, Albano E, Bellomo $G$. When and why a water-soluble antioxidant becomes pro-oxidant during copper-induced low-density lipoprotein oxidation: a study using uric acid. Biochem J. 1999 May 15;340 ( Pt 1)(Pt 1):143-52.

10. Sánchez-Lozada LG, Tapia E, Santamaría J, AvilaCasado $C$, Soto $V$, Nepomuceno $T$, et al. Mild hyperuricemia induces vasoconstriction and maintains glomerular hypertension in normal and remnant kidney rats. Kidney Int. 2005;67(1):237-47. doi: 10.1111/j.1523-1755.2005.00074.x. 
11. Johnson RJ, Perez-Pozo SE, Sautin YY, et al. Hypothesis: could excessive fructose intake and uric acid cause type 2 diabetes? Endocr Rev. 2009;30:96-116. doi: 10.1210/er.2008-0033.

12. Demikhov O, Dehtyarova I, Demikhova N. Actual aspects of public health policy formation on the example of Ukraine. Bangladesh Journal of Medical Science 2020; 19(3):358-364. doi:10.3329/bjms. v19i3.45850.

13. Коли безсимптомна гіперурікемія потребує лікування? Український ревматологічний журнал 2020;79(1):40-46. doi: 10.32471/rheumatology.2707-6970.79.14918

14. Demihova $N$, Lidiya $C$, Chernatska O, Mazur T, Aleksakhina T, Demikhov O. The Relationship Between Lipid Metabolism and The Level of Albuminuria with Single Nucleotide Polymorphism -204A>C [rs 3808607] CYP7A1 Gene in Patients with Type 2 Diabetes Mellitus and Diabetic Nephropathy. Romanian Journal of Diabetes Nutrition and Metabolic Diseases. 2019;26(3): 253-260. doi: 10.2478/rjdnmd-2019-0026.Feig DI, Kang DH, Johnson RJ. Uric acid and cardiovascular risk [published correction appears in N Engl J Med. 2010;362(23):2235]. N Engl J Med. 2008;359(17):1811-1821. doi:10.1056/ NEJMra0800885

15. Stepanova N, Snisar L, Lebid L. Hyperuricemia Predicts Residual Diuresis Decline in Peritoneal Dialysis Patients. Electron J Gen Med. 2021;18(1):em270. doi: 10.29333/ejgm/9297.

16. El Ridi R, Tallima $H$. Physiological functions and pathogenic potential of uric acid: A review. J Adv Res. 2017;8(5):487-493. doi:10.1016/j. jare.2017.03.003.

17. Son CN, Kim JM, Kim SH, et al. Prevalence and possible causes of hypouricemia at a tertiary care hospital. Korean J Intern Med. 2016;31(5):971976. doi:10.3904/kjim.2015.125.

18. Bairaktari ET, Kakafika AI, Pritsivelis $N$, Hatzidimou KG, Tsianos EV, Seferiadis KI, et al. Hypouricemia in individuals admitted to an inpatient hospital-based facility. Am J Kidney Dis. 2003 Jun;41(6):1225-32. doi: 10.1016/s02726386(03)00355-x.

19. Chaudhary K, Malhotra K, Sowers J, Aroor A. Uric Acid - key ingredient in the recipe for cardiorenal metabolic syndrome. Cardiorenal Med. 2013;3(3):208-220. doi: 10.1159/000355405.
20. Shi $Y$, Chen $W$, Jalal D, Li Z, Chen $W$, Mao $H$, et al. Clinical outcome of hyperuricemia in IgA nephropathy: a retrospective cohort study and randomized controlled trial. Kidney Blood Press Res. 2012;35(3):153-60. doi: 10.1159/000331453.

21. Stepanova N, Burdeyna O, Snisar L. Hyperuricemia is associated with cardiovascular events and allcause mortality in peritoneal dialysis patients. Nephr Dial Transpl. 2019;34(1):i242. doi:10.1093/ ndt/gfz106.FP587.

22. Stepanova N, Snisar L, Lebid L, Savchenko S, Nepomnyashchii $V$, Kolesnyk M. Serum uric acid and renal survival prognosis in primary glomerulonephritis patients in a retrospective single-center cohort. J Renal Inj Prev 2021;10(2): e11-e11. doi: 10.34172/jrip.2021.11.

23. Vasylchenko V, Korol L, Kuchmenko O, Stepanova $N$. The oxidative status in patients with chronic kidney disease. Ukr Biochem J 2020;92(5):70-77. doi: 10.15407/ubj92.05.070.

24. Sowers JR. Diabetes mellitus and vascular disease. Hypertension. 2013;61(5):943-7. doi: 10.1161/ HYPERTENSIONAHA.111.00612.

25. Jalal DI, Rivard CJ, Johnson RJ, Maahs DM, McFann K, Rewers $M$, et al. Serum uric acid levels predict the development of albuminuria over 6 years in patients with type 1 diabetes: findings from the Coronary Artery Calcification in Type 1 Diabetes study. Nephrol Dial Transplant. 2010 Jun;25(6):1865-9. doi: 10.1093/ndt/gfp740.

26. Kolesnyk M, Stepanova $N$, Snisar L, Lebid L, Nepomnyaschii $V$, Savchenko $S$. Uric acid and the risk of kidney failure in primary glomerulonephritis patients with nephrotic syndrome: preliminary results of an ongoing single-center prospective study. Ukr J Nephr Dial. 2020;1(65):29-35. doi: 10.31450/ ukrjnd.1(65).2020.05.

27. Lipkowitz MS. Regulation of Uric Acid Excretion by the Kidney. Curr Rheumatol Rep 2012;14(2):17988. doi: 10.1007/s11926-012-0240-z.

28. Ryu ES, Kim MJ, Shin HS, Jang YH, Choi HS, Jo I, Johnson RJ, Kang DH. Uric acid-induced phenotypic transition of renal tubular cells as a novel mechanism of chronic kidney disease. Am J Physiol Renal Physiol. 2013 Mar 1;304(5):F471-80. doi: 10.1152/ajprenal.00560.2012. 